\title{
Formulasi Model Perkuliahan Daring Sebagai Upaya Menekan Disparitas Kualitas Perguruan Tinggi (Studi terhadap Website pditt.belajar.kemdikbud.go.id)
}

\author{
Mokhamad Iklil Mustofa ${ }^{1}$, Muhammad Chodzirin², Lina Sayekti ${ }^{3}$ \\ 1,2,3 Universitas Islam Negeri Walisongo Semarang
}

\begin{abstract}
A one-step using network technology and information technology for the development of learning system in universities is online lecturing system. College student that lives in isolated area can access the subjects of reputable universities in Indonesia. The object of this study is on website pditt.belajar.kemdikbud.goid. This website is developed by the Ministry of Education and Culture Indonesia. The selection of that locus is because the website is an official website of government which collaborate with some reputable universities in Indonesia, such as University of Indonesia, Bandung Institute of Technology, Gajahmada University, Sepuluh November Institut of Technology, Aptikom, and Bina Nusantara University. The result showed that online lecturing system has positive contribution for pushing the quality disparity of universities in Indonesia. The indications such as 1) Minimize the limitation of access to higher education that have a certain quality. 2) Cut-off the limitation of facilities that had been cosidered as one of obstacles of the lower quality of higher education. 3) Eliminate the limitation of understanding to certain material. 4) Online lecturing system gives wide access to educational resources, especially in reputable universities.
\end{abstract}

Keyword : e-learning, information system, education, information technology

\begin{abstract}
Abstrak
Satu langkah maju dalam menggunakan teknologi jaringan dan teknologi informasi untuk pengembangan sistem pembelajaran di universitas adalah sistem kuliah online. Mahasiswa yang tinggal di daerah terpencil dapat mengakses mata pelajaran universitas terkemuka di Indonesia. Oleh karena itu, perbedaan kualitas universitas akan berkurang. Objek penelitian ini ada di situs web pditt.belajar.kemdikbud.go.id. Pemilihan lokus tersebut adalah karena situs web tersebut adalah situs resmi pemerintah yang bekerja sama dengan beberapa universitas terkemuka di Indonesia, seperti Universitas Indonesia, Institut Teknologi Bandung, Universitas Gajahmada, Institut Teknologi Sepuluh November, Aptikom, dan Universitas Bina Nusantara . Hasil penelitian menunjukkan bahwa sistem kuliah online memiliki kontribusi positif untuk mendorong disparitas kualitas perguruan tinggi di Indonesia. Indikasi seperti 1) Meminimalkan keterbatasan akses ke pendidikan tinggi yang memiliki kualitas tertentu. 2) Memotong keterbatasan fasilitas yang telah dipertimbangkan sebagai salah satu kendala dari rendahnya kualitas pendidikan tinggi. 3) Menghilangkan batasan pengertian pada materi tertentu. 4) Sistem kuliah online memberikan akses luas ke sumber daya pendidikan, terutama di universitas terkemuka.
\end{abstract}

Kata kunci : e-learning, sistem informasi, pendidikan, teknologi informasi

ISSN 2715-0143 (online) ISSN 2714-9048 (print)

http://journal.walisongo.ac.id/index.php/jit/index

WJIT : Walisongo Journal of Information Technology - Vol.1 No. 2 (2019) 


\section{PENDAHULUAN}

Sistem pembelajaran modern berbasis teknologi informasi memberikan kualitas luasnya jangkauan yang sangat cocok untuk masyarakat milineal yang dapat diakses di berbagai tempat dan waktu. Sistem ini dapat diakses oleh berbagai level masyarakat dari menengah samapai sedang. Revolusi industri 4.0 memudahkan orang untuk terhubung secara online, seperti media sosial dan dapat mengakses informasi dengan cepat.

$$
\text { Salah satu langkah }
$$

pemanfaatan teknologi jaringan dan teknologi informasi bagi pengembangan sistem pembelajaran di perguruan tinggi adalah sistem kuliah daring (dalam jaringan) antar perguruan tinggi. Salah satu pemrakarsa dari sistem ini adalah Kementerian Pendidikan dan Kebudayaan Republik Indonesia. Kemendikbud melalui Direktorat Jenderal Pendidikan Tinggi membuat website pditt.belajar.kemdikbud.go.id yang diharapkan dapat menjadi sarana yang efektif bagi para pelajar dalam mempelajari ilmu tanpa batas. Proses belajar dengan cara ini dinilai sangat baik, karena sumber belajar dapat digunakan dengan gratis oleh ribuan orang yang membutuhkan. Jadi mahasiswa dari perguruan tinggi yang ada di daerah terpencil dapat mengakses mata kuliah di perguruan tinggi terkemuka di Indonesia. Proses belajar ini akan menarik mahasiswa, karena penyampaian data yang disiapkan dalam media tersebut menyenangkan, dan mudah untuk dicerna, sehingga membuat mahasiswa menjadi ingin lebih tahu. Konten yang lengkap, jelas, menumbuhkan minat belajar, akan semakin digemari sampai tumbuhnya masyarakat yang cerdas, kaya pengetahuan, bahkan sampai berkemampuan mengembangkan ilmu pengetahuannya melalui percobaan, penelitian, kajian yang akhirnya akan berdaya dengan pengembangan kompetensinya. Untuk memperkaya konten sumber belajar ini Kemendikbud bekerjasama dengan perguruan tinggi terkemuka di Indonesia yang memiliki ilmuwan, peneliti, innovator, dan co-kreator dalam bidang teknologi informasi dan komunikasi serta berpengetahuan dalam bidangnya. Idealnya, apabila sumber belajar ini mampu diakses oleh banyak pengguna, murah, dan dinamis, seyogyanya dapat diproduksi oleh dosen di perguruan tinggi dalam rangka menumbuh kembangkan technopreneurship perguruan tinggi.

Langkah konstruktif dari Kemendikbud tersebut diambil mengingat masih terdapat disparitas kualitas perguruan tinggi di Indonesia. Beberapa indikator dari disparitas kualitas perguruan tinggi tersebut adalah: 1) Masih banyak perguruan tinggi yang kapasitasnya sangat terbatas. 2) Keterjangkauan perguruan tinggi yang rendah dikarenakan sebaran yang kurang merata mengakibatkan peningkatan biaya kuliah dan akomodasinya. 3) Sebagian besar perguruan tinggi belum memiliki sumber daya pendidikan yang memadai dan berkualitas. 4) 
Perguruan tinggi bermutu lebih tersentral di pulau Jawa sehingga mahasiswa yang ada di luar Jawa kurang memiliki akses pendidikan yang baik dan berkualitas. 5) Banyak perguruan tinggi yang masih dalam tahap inkubasi/bimbingan oleh pemerintah dalam menyediakan layanan yang memuaskan 6) Perguruan tinggi masih rendah dalam menjamin pemenuhan lulusan yang bermutu (Kementerian Pendidikan dan Kebudayaan RI, 2014: 2).

Melihat urgensifitas dari sitem perkuliahan daring ini dan adanya fenomena disparitas kualitas perguruan tinggi, maka penelitian ini dilakukan untuk menjawab permasalahan disparitas tersebut. Mengingat masih banyak perguruan tinggi yang masih meragukan keberhasilan sistem pembelajaran online. Dosen masih setengah hati atau bahkan takut untuk melaksanakan perkuliahan online. Hasil penelitian ini diharapkan dapat menjadi angin segar bagi pengembangan formulasi model pembelajaran online di perguruan tinggi.

Berdasarkan gambaran latar belakang di atas dalam penelitian ini akan mengkaji dan menjawab rumusan masalah sebagai berikut: Pertama, bagaimana formulasi model pembelajaran daring lintas perguruan tinggi melalui website pditt.belajar.kemdikbud.go.id? Kedua, bagaimana kontribusi formulasi model pembelajaran daring dalam menekan disparitas kualitas perguruan tinggi?

\section{Konsep Dasar Model Perkuliahan Melalui Daring}

Pemanfaatan

teknologi

telekomunikasi untuk kegiatan pembelajaran di sekolah di Indonesia semakin kondusif dengan munculnya sistem perkuliahan daring. Istilah daring merupakan akronim dari "dalam jaringan". Jadi perkuliahan daring adalah salah metode pembelajaran online atau dilakukan melalui jaringan internet. Sistem perkuliahan daring ini dikembangkan oleh Kementerian Pendidikan dan Kebudayaan Republik Indonesia melalui Program Kuliah Daring Indonesia Terbuka dan Terpadu (KDITT). KDITT merupakan program pemerintah dalam menjangkau pelajar skala nasional (Kementerian Pendidikan dan Kebudayaan RI, 2014: 1).

Tujuan dari Program Kuliah Daring Indonesia Terbuka Terpadu menurut Kementerian Pendidikan dan Kebudayaan RI, (2014: xv) adalah sebagai berikut :

1. Meningkatkan ketersediaan layan an pendidikan

2. Meningkatkan keterjangkauan la yanan pendidikan

3. Meningkatkan kualitas/mutu dan relevansi layanan pendidikan

4. Meningkatkan kesamaan dalam mendapatkan mutu layanan pendidikan, dan

5. Meningkatkan kepastian/keterjaminan mendap atkan mutu layanan pendidikan yang baik.

Ada tiga hal yang berkaitan dengan pengembangan perkuliahan 
daring, yakni konten, kanal, infrastruktur atau teknologi informasi (Tl) (http://fri.or.id). Berkaitan dengan pra syarat pembelajaran daring ada tiga hal yang perlu dilengkapi yaitu: (a) proses belajar mengajar dilaksanakan melalui koneksi internet, (b) tersediannya fasilitas untuk kaum pelajar dalam layanannya, seperti cetak, dan (c) disediakannya tutor jika terjadi kesulitan dalam proses belajar (Newsletter of ODLQC, 2001). Selain hal itu, ada tambahan persyaratan lain, seperti: (a) pihak penyelenggara kegiatan e-learning, (b) maindset positif dosen dan mahasiswa dalam fungsi utama internet, (c) desain sistem proses belajar yang bisa dipelajari oleh semua mahasiswa, (d) adanya proses evaluasi dari rangkaian proses belajar mahasiswa, dan (e) mekanisme feedback dari pihak penyelenggara.

Dengan demikian, secara sederhana dapatlah dikatakan bahwa pembelajaran daring merupakan kegiatan pembelajaran yang memanfaatkan jaringan (Internet, LAN, WAN) sebagai metode penyampaian, interaksi, dan fasilitasi serta didukung oleh berbagai bentuk layanan belajar lainnya (http://eyepopping.manilasites.com/ profiles/).

Manfaat pembelajaran daring menurut Bates dan Wulf terdiri atas 4 hal, yaitu: 1) Meningkatkan kadar interaksi pembelajaran antara peserta didik dengan guru atau instruktur (enhance interactivity), 2) Memungkinkan terjadinya interaksi pembelajaran dari mana dan kapan saja (time and place flexibility), 3) Menjangkau peserta didik dalam cakupan yang luas (potential to reach a global audience), 4) Mempermudah penyempurnaan dan penyimpanan materi pembelajaran (easy updating of content as well as archivable capabilities) (Bates, 1997: 15).

Implementasi pembelajaran daring dengan demikian dapat memberikan manfaat antara lain : 1) Adanya kenaikan grafik kualitas perguruan tinggi dan kualitas lulusan, 2) Terbentuknya komunitas sharing ilmu tidak terbatas dalam satu lokasi, 3) peningkatan komunikasi yang intens antara dosen dan mahasiswa, 4) Tidak terbatasnya sumber-sumber belajar, 5) meningkatnya kualitas dosen dikarenakan mudah dosen dalam mendapatkan informasi.

Mengadaptasi Khoe Yao Tung, karakteristik pembelajaran daring, antara lain: 1) Materi ajar disajikan dalam bentuk teks, grafik dan berbagai elemen multimedia, 2) Komunikasi dilakukan secara serentak dan tak serentak seperti video conferencing, chats rooms, atau discussion forums, 3) Digunakan untuk belajar pada waktu dan tempat maya, 4) Dapat digunakan berbagai elemen belajar berbasis CD-ROM, untuk meningkatkan komunikasi belajar, 5) Materi ajar relatif mudah diperbaharui, 6) Meningkatkan interaksi antara mahasiswa dan fasilitator, 7) Memungkinkan bentuk komunikasi belajar formal dan informal, 7) Dapat menggunakan ragam sumber belajar yang luas di internet (Tung, 2000: 15). 
Menurut Khan B.H, menjelaskan terdapat beberapa kegiatan yang harus ada dalam pembelajaran daring, yaitu: 1) Meningkatkan perhatian mahasiswa, 2) Menyampaikan tujuan belajar kepada mahasiswa, 3) Mendorong ingatan kembali mahasiswa tentang informasi yang telah dipelajarinya, 4) Menyajikan stimuli secara khusus, 5) Memberi petunjuk belajar, 6) Memperoleh performan mahasiswa, 7) Memberikan umpan balik yang informatif, 8) Menilai tingkat performan mahasiswa, 9) Meningkatkan retensi dan transfer belajar (Khan, 1997: 102).

Keberhasilan sistem pembelajaran daring sangat tergantung dari beberapa komponen baik mahasiswa, dosen, sumber belajar, maupun teknologi informasi. Komponen-komponen tersebut terintegrasi supaya benar-benar dapat menghasilkan lulusan mahasiswa yang berkualitas juga.

\section{METODE}

Penelitian ini termasuk jenis penelitian deskriptif kualitatif. Penelitian ini berupaya untuk mempelajari masalah-masalah yang berkaitan dengan sistem pembelajaran daring (dalam jaringan) dan disparitas kualitas perguruan tinggi. Teknik pengumpulan data yang penulis gunakan dalam penelitian ini ialah observasi dan kajian dokumen (Suharsimi, 2006: 16). Peneliti melakukan observasi dan eksplorasi terhadap sistem pembelajaran daring di

pditt.belajar.kemdikbud.go.id.

Beberapa komponen yang di observasi adalah daftar mata kuliah, daftar dosen pengampu, daftar materi terbuka, konsultasi dan tanya jawab, ruang diskusi dosen, dan ruang diskusi mahasiswa.

Disamping itu peneliti akan menelaah dokumen-dokumen yang terkait dengan sistem pembelajaran daring, di antaranya adalah materi kuliah, daftar dosen, daftar mahasiswa dan lain sebainya. Metode yang digunakan dalam menganalisis data penelitian ini adalah deskriptifinterpretatif. Siklus analisis dalam penelitian ini menggunakan siklus interaktif yang didalamnya terdiri dari: sajian data (data display), reduksi data (data reduction), dan visualisasi kesimpulan (conclusion visualisation) (Faisal, 2001: 256).

\section{HASIL DAN PEMBAHASAN}

1. Formulasi Model Pembelajaran Daring Lintas Perguruan Tinggi Melalui Website pditt.belajar.kemdikbud.go.id

Pembelajaran Daring Indonesia Terbuka dan Terpadu (PDITT) merupakan salah satu bentuk pemanfaatan teknologi dalam pembelajaran. PDITT berfungsi agar dapat menjembatani, meminimalisasi gap ketersediaan, keterjangkauan, dan kualitas pendidikan tinggi di Indonesia. Pada web ini, mahasiswa yang telah terhubung dapat mengakses beberapa mata kuliah yang disajikan dimana pun, dan kapan pun diinginkan. Mata kuliah 
yang ditawarkan di PDITT bisa diikuti oleh mahasiswa dari perguruan tinggi manapun oleh masyarakat umum.

Persyaratan yang harus dipenuhi untuk mengikuti kegiatan perkuliahan disini adalah memastikan SKS, kontrak mata kuliah dan persyaratan akademik internal kampus asal mahasiswa. Mahasiswa telah melakukan pendaftaran di perguruan tinggi masing-masing. Sehingga database yang dimasukkan disini dapat valid sesuai dengan data yang diberikan pihak universitas.

Mahasiswa dapat mengakses materi dimana saja dan kapan saja, selama masih dalam tenggang waktu yang telah disepakati sebelumnya. Selain itu, mahasiswa berkesempatan untuk menerima materi langsung dari para dosen tetap perguruan tinggi Penyelenggara. Seluruh Perguruan Tinggi Penyelenggara, merupakan beberapa perguruan tinggi yang telah ditunjuk pihak Kementerian Pendidikan dan Kebudayaan untuk menyelenggarakan program pendidikan jarak jauh ini, di antaranya adalah Universitas Indonesia, Institut Teknologi Bandung, Istitut Teknologi Sepuluh Nopember, Universitas Gadjah Mada, Universitas Bina Nusantara, dan STMIK Amikom Yogyakarta. Program ini sengaja dirancang oleh Direktorat Pendidikan Tinggi guna membendung gap ketersediaan bahan kuliah, materi ajar dan lain sebagainya. Sehingga dipastikan bahwa sertifikat yang mahasiswa dapatkan legal dan mampu dipertanggungjawabkan.

Bobot nilai yang diberikan berbeda dengan perguruan tinggi asal. Hal ini dikarenakan masingmasing perguruan tinggi memiliki standar penilaian masing-masing. Nilai yang mahasiswa dapatkan disini, akan dikonversi oleh pihak Universitas asal untuk disesuaikan.

Kegiatan perkuliahan telah diatur dalam jangka waktu tertentu. Mahasiswa dapat mengakses materi pada sebuah mata kuliah sesuai dengan waktu yang telah ditentukan. Biasanya setiap topic diakses dalam waktu satu minggu, namun itu tergantung dari banyak/tidaknya materi di dalam sebuah mata Kuliah.

Model Pembelajaran yang ditawarkan berbeda-beda sesuai dengan materi yang diberikan. Namun mayoritas mata kuliah PDITT menggunakan modul, video/animasi dan forum diskusi sebagai bahan pembelajaran, lalu diakhiri dengan tugas/kuis di setiap minggunya.

Bentuk penilaian biasanya ada yang berupa penilaian tugas kelompok maupun individu, membuat product, dan kuis. Namun hal ini tergantung dari mata kuliah yang bersangkutan. Mahasiswa dapat melihat detailnya di deskripsi Mata Kuliah yang bersangkutan.

Di bagian beranda website pditt.belajar.kemdikbud.go.id ada empat menu utama yang ditampilkan yaitu: 1) Mata Kuliah Daring, yang merupakan kumpulan sumber dan aktivitas pembelajaran dalam satu paket Mata Kuliah yang dapat diakses secara daring, sesuai standar proses dan standar isi, dan memperoleh sertifikat yang dapat dialihkreditkan, 2) Mata Kuliah Terbuka, yaitu kumpulan sumber belajar atau aset 
digital yang dikemas dalam satu paket Mata Kuliah yang dapat diakses dan dimanfaatkan secara terbuka untuk umum. 3) Materi Terbuka, berisi sumber belajar atau aset digital yang dapat diakses dan dimanfaatkan secara terbuka untuk umum. Beberapa materi yang dapat diakses di antaranya adalah Pendidikan Agama Khonghucu, Pendidikan Agama Kristen, Pendidikan Agama Katholik, Pendidikan Agama Islam, Pendidikan Agama Budha, Pendidikan Agama Hindu, Koleksi Kuliah Umum Universitas Indonesia (13 koleksi), Teknik Pengendalian Pencemaran Udara, Perencanaan Bangunan Pengolahan Air Buangan, Pengelolaan Buangan Industri, Pengantar Pengelolaan Prasarana Lingkungan Permukiman, Evalaluasi Perencanaan Prasarana Lingkungan Permukiman (std), Ekotoksikologi , Bioteknologi Lingkungan, Joni Hermana, Academic Presentation, dan Prasarana Lingkungan Perumahan. 4) Forum Diskusi, yang digunakan sebagai sarana diskusi antar mahasiswa, dosen dengan mahasiswa, dosen dengan dosen, dan mahasiswa dengan penyelenggara.

Untuk akses penuh pada Mata Kuliah pengguna perlu membuat keanggotaan baru pada situs ini. Setiap Mata Kuliah juga nantinya akan membutuhkan password. Beberapa langkah yang dapat dilakukan untuk dapat mengakses mata kuliah daring adalah sebegai berikut: 1) Pengguna mengisi formulir Anggota baru, 2) Sebuah email akan dikirimkan ke alamat email pengguna, 3) Baca email yang dikirimkan, dan klik pada link situs yang ada, 4) Keanggotaan pengguna akan dikonfirmasikan dan pengguna mulai bisa login, 5) Setelah login, pilih Mata Kuliah yang ingin diikuti, 6) Jika diminta untuk memasukkan password maka masukkan kata kunci yang diberikan oleh pengajar. Ini akan "mendaftarkan" pengguna pada Mata Kuliah.

Selanjutnya pengguna dapat mengakses penuh Mata Kuliah tersebut. Pengguna hanya perlu memasukkan nama pengguna dan password untuk Login dan mengakses mata kuliah yang telah didaftar. Model pembelajaran dalam sistem kuliah daring berpusat kepada mahasiswa. Model pembelajaran ini berbasis pada projek. Adapun tahapan pembelajarannya adalah sebagai berikut:

a. Inisiasi

Mengambil topik yang sesuai dengan realitas dunia nyata dan dimulai dengan sebuah inverstigasi mendalam. Pertanyaan esensial diajukan untuk memancing pengetahuan, tanggapan, kritik dan ide mengenai tema proyek yang akan diangkat.

b. Perencanaan

Perencanaan berisi tentang aturan main, pemilihan aktivitas yang dapat mendukung dalam menjawab pertanyaan esensial dengan cara mengintegrasikan berbagai subyek yang mungkin, serta mengetahui alat dan berbagai bahan yang dapat diakses untuk membantu penyelesaian proyek. 
c. Penjadwalan

Pendidik dan peserta didik secara kolaborasi menyusun jadwal aktivitas dalam menyelesaikan proyek. Jadwal ini disusun untuk mengetahui berapa lama waktu yang dibutuhkan dalam pengerjaan proyek.

\section{d. Pengawasan}

Pendidik bertanggung jawab untuk melakukan monitor terhadap aktivitas peserta didik selama menyelesaikan proyek. Monitoring dilakukan dengan cara memfasilitasi peserta didik dalam setiap proses.

e. Penilaian

Penilaian dilakukan untuk membantu pendidik dalam mengukur pancapaian standar, berperan dalam mengevaluasi kemajuan masingmasing peserta didik, memberi umpan balik tentang tingkat pemahaman yang sudah dicapai peserta didik, membantu pendidik dalam menyusun strategi pembelajaran berikutnya.

f. Evaluasi

Pada akhir proses pembelajaran, pendidik dan peserta didik melakukan refleksi terhadap aktivitas dan hasil proyek yang telah dijalankan. Proses refleksi dilakukan baik secara individu maupun kelompok. Pada tahap ini peserta didik diminta untuk mengungkapkan perasaan dan pengalamnnya selama menyelesaikan proyek.

\section{Kontribusi Sistem \\ Pembelajaran Daring dalam Menekan Disparitas Kualitas Perguruan Tinggi}

Materi pembelajaran daring merupakan seperangkat informasi bidang ilmu yang terstruktur untuk pembelajaran yang disajikan dalam bentuk elektronik. Materi yang disajikan ini memuat berbagai bahan dari disiplin ilmu yang ada, sehingga dapat mudah dicari dan diakses tanpa terbatas oleh waktu dan tempat. Semua bahan yang disediakan dapat diakses secara bersamaan, mudah dibagi, dan kecepatan dalam pencarian. Semua mahasiswa dari berbagai macam dan jenis perguruan tinggi dapat memanfaatkan pembelajaran ini, sehingga tidak ada pemikiran negatif bagi mahasiswa terhadap perguruan tinggi yang menaunginya itu tidak berkualitas.

Materi yang ada dalam sistem pembelajaran daring berbeda dengan materi pembelajaran konvensional. Materi pembelajaran daring bersifat digital sehingga membutuhkan bantuan perangkat teknologi. Oleh karena itu, pengembangan sistem pembelajaran daring memiliki keunggulan dibandingkan sistem konvensional, yaitu:

1. Menggunakan teknologi yang murah dan tersedia saat ini. Teknologi yang digunakan hanya menggunakan reader pdf dan flash reader karena file yang disediakan berformat *.pdf fan *.swf.

2. Menggunakan teknologi yang memungkinkan interaksi langsung di laman tersebut, dan merekam jejak penggunaan materi untuk dapat membandingkan kemajuan pengguna dalam memahami materi yang disampaikan. 
3. Menggunakan teknologi yang bersifat device independent, sehingga dapat diakses dengan perangkat $\mathrm{PC}$, notebook, tablet, ataupun smartphone.

4. Menggunakan teknologi multimedia untuk memberikan ilustrasi yang menarik sehingga dapat menggugah peserta didik agar tertarik mempelajari materi.

5. Mendeskripsikan informasi tentang materi dalam bentuk metadata dalam bahasa Extensible Markup Language (XML), sehingga materi lebih diakses melalui internet.

6. Mengemas materi sehingga compliant terhadap ISO/IEC TR 29163 tentang Sharable Content Object Reference Model. Sehingga materi yang ditawarkan dapat diunduh oleh siapapun dimanampun dia berada.

\section{PENUTUP}

Formulasi model perkuliahan dalam jaringan (daring) merupakan sistem pembelajaran jarak jauh yang menggunakan bantuan teknologi. Mahasiswa dan dosen tidak perlu melakukan tatap muka selama proses pembelajaran berlangsung. Di samping itu semua materi dan tugas pembelajaran dilakukan secara online.

Sistem perkuliahan daring memiliki kontribusi positif untuk menekan disparitas kualitas perguruan tinggi yang ada di Indonesia. Beberapa indikasinya di antaranya adalah 1) meminimalisir keterbatasan akses pendidikan tinggi yang berkualitas, karena perguruan tinggi yang ada di daerah terpencil dapat mengakses pendidikan tinggi berkualitas yang ada di kota-kota besar. 2) memutus keterbatasan fasilitas yang selama ini dianggap sebagai salah satu kendala rendahnya kualitas pendidikan tinggi. Sistem kuliah daring tidak membutuhkan fasilitas yang super canggih dan mahal, cukup menggunakan PC, notebook, tablet, ataupun smartphone, yang saat ini harganya cukup terjangkau oleh masyarakat. 3) menghilangkan keterbatasan pemahaman terhadap materi tertentu. Sistem kuliah daring memberikan pemahaman yang lebih komprehensif dari pada sistem konvensional, karena materi ditampilkan secara digital dan dalam bentuk animasi. 4) Sistem kuliah daring memberikan akses yang luas terhadap sumber daya pendidikan, khususnya yang ada di perguruan tinggi tekemuka. 


\section{REFERENCES}

Arikunto, Suharsimi, Prosedur Penelitian: Suatu Pendekatan Praktik, Jakarta : Rineka Cipta, 2006.

Bates, T., The Impact of Technological Change on Open and Distance Learning. Distance Education, 1997.

Faisal, Sanafiah, Format-format Penelitian, Jakarta: PT. Raja Grafindo Persada, 2001.

Kementerian Pendidikan dan Kebudayaan RI, Panduan Pengembangan dan Penyelenggaraan KDITT, Jakarta: Kemendikbud, 2014.

Khan, B.H., Web Based Instruction, Educational Technology Publications. New Jersey: Englewood Cliffs, 1997).

Tung, Khoe Yao, Pendidikan dan Riset di Internet, Jakarta: Dinastindo, 2000. 